\title{
COMMENT
}

EC Perspective

\section{Brazil's evolving proposal to control deforestation: Amazon still at risk}

Brazil's National Plan for Climate Change (PNMC [Plano Nacional sobre Mudança do Clima]) (Brazil, Comitê Interministerial sobre Mudança do Clima 2008) brought the good news of quantified goals for deforestation reduction in Brazilian Amazonia, a departure from past policy, under which the Brazilian government has steadfastly refused any quantitative goals for deforestation reduction in the context of reducing greenhouse gas emissions. Contrary to many press reports, the PNMC does not contain 'targets' (metas), using instead the term 'objectives' (objetivos) (Brazil, Comitê Interministerial sobre Mudança do Clima 2008, p. 11). The distinction is important, as the latter implies no consequences for exceeding these amounts of deforestation, and, indeed, no such consequences are mentioned in the report, such as Brazil purchasing carbon credit to make up for any shortfall in the amount of emissions reduction actually achieved. Nevertheless, the report has the potential to contribute to efforts by Brazilian civil society to pressure the government if the PNMC's 'objectives' are ignored in the future.

The plan leaves a wide escape hatch for not achieving the reduction objectives by implying that they are conditional on international donations, presumably to the Amazon Fund (Fundo Amazônia), a fund set up to administer money received as a large donation from Norway plus any other such voluntary contributions that other countries may make in the future towards Brazil's efforts to reduce Amazonian forest loss. No carbon credit is given for the donations or for resulting deforestation reductions, as the Brazilian Ministry of External Relations opposes use of reduced emissions from deforestation and degradation (REDD) for carbon trading that would be valid against the assigned amounts (emissions quotas) of countries with national emissions limits under the Kyoto Protocol or its successor. This insistence on strictly voluntary donations greatly limits the potential volume of funds that are likely to materialize. If the countries of the world become serious about controlling global warming, they will need to make commitments that go far beyond what they found difficult to achieve under the Kyoto Protocol. Under the Kyoto Protocol, fossil fuel emissions of developed (Annex I) countries were to be cut by an average of only 5.8\% relative to 1990 ; what is required is a cut in global total emissions (including all countries of the world and deforestation as well as fossil fuels) by an amount of the order of $80 \%$ relative to 1990 (see for example Hare \& Meinshausen 2006; Meinshausen et al. 2009). Achieving this would require all available funds to be used to meet formal commitments, leaving nothing left over for voluntary programmes that yield no credit towards the national quotas. The argument of Brazil's negotiators that the voluntary fund is better because it is in addition to the formal reductions could only apply if the formal commitments were already fixed, which will not be the case at least until COP15 (the 15th Conference of the Parties under the United Nations' Climate Change Convention) to be held in Copenhagen in December 2009. With the commitments still undecided, keeping avoided deforestation out of the formal crediting system only means that countries will agree to smaller cuts in their emissions, thereby cancelling any supposed climate benefit of the voluntary scheme.

It is significant that the PNMC makes no comment on the definition of 'dangerous' climate change, as must now be defined under the climate convention (UN-FCCC [United Nations Framework Convention on Climate Change] 1992, Article 2). This maximum permitted limit on atmospheric concentrations of greenhouse gases is what will determine both the magnitude of future global warming and the level of mitigation commitments that must be made. Defining a maximum concentration will change the nature of the discussion completely, as maintaining the concentrations of greenhouse gases below their agreed limits means that all emissions count, regardless of whether they are 'direct human induced' emissions, or come from poor countries or rich countries, for example. If an emission occurs from a forest fire, hydroelectric dam or warming soil under global warming, the petty arguments over what is included in national greenhouse gas inventories and in Kyoto Protocol emissions accounting will not matter, as the atmosphere is indifferent to all the gaming, loopholes and diplomatic doublespeak that abound today. Brazil's negotiators steadfastly rejected the $2^{\circ} \mathrm{C}$ temperature increase proposed by the European Union as the definition of 'dangerous interference with the global climate system' until July 2009, when Brazil's president Luiz Inácio Lula da Silva endorsed this goal at the G7 meeting in Aquila, Italy. Considering that over 100 countries had by then endorsed the $2^{\circ} \mathrm{C}$ limit, Brazil was one of the last countries to get on the bandwagon. The long delay implied the desire on the part of Brazil's diplomats to have a higher limit set, or to postpone any limit for as long as possible, would not just have the effect of relieving Brazil from some international pressure to reduce emissions and deforestation, but would also place the Amazon forest at risk of die-off from climate change (see for example Cox et al. 2008). The tipping point to Amazon dieback may well be before $2^{\circ} \mathrm{C}$ if the impact of deforestation and fire is added to climate change; it is therefore likely that the $2^{\circ} \mathrm{C}$ limit endorsed in Aquila will need to be lowered.

The reduction in Amazonian deforestation under the PNMC is not nearly as much as it would appear to be from the $40 \%$ figure emphasized in the PNMC document and in the press. The baseline against which the $40 \%$ reduction for 
the 2006-2009 period is measured is the average deforestation rate over the 1996-2005 period $\left(19508 \mathrm{~km}^{2} \mathrm{yr}^{-1}\right)$, making the $40 \%$ target for 2006-2009 equivalent to a deforestation rate of $11705 \mathrm{~km}^{2} \mathrm{yr}^{-1}$. The total deforestation permitted for this four-year period would therefore be $4 \times 11705=$ $46819 \mathrm{~km}^{2}$. The deforestation for 2006, 2007 and 2008 totalled $38740 \mathrm{~km}^{2}$, leaving $8079 \mathrm{~km}^{2}$ to be cleared in 2009 . A preliminary estimate for deforestation in 2009 indicates $7008 \mathrm{~km}^{2}$, based on 92 satellite images out of the approximately 215 normally used for a full estimate. The actual amount will only be known in March 2010 when the final estimate for the year is released (see URL http://www.obt.inpe.br/prodes/). The decline over the 2006-2009 period is the result of various factors, including the international prices of soy and beef and an unfavourable exchange rate for the Brazilian real against the US dollar (see Nepstad et al. 2006). Repression of deforestation undoubtedly had some effect, but the government has collected very few of the fines levied against illegal deforesters (Brito 2009; Lima et al. 2009).

A substantial amount of clearing is still allowed under the announced plan. The target over the next four-year period (2010-2013) would be $30 \%$ below the preceding four-year period, meaning that $8193 \mathrm{~km}^{2} \mathrm{yr}^{-1}$ would be permitted. Likewise, the $30 \%$ reduction for 2014-2017 would permit average deforestation of $5735 \mathrm{~km}^{2} \mathrm{yr}^{-1}$. The total amount of clearing allowed for the 2009-2017 period is therefore $80112 \mathrm{~km}^{2}$, or almost three Belgiums. The average deforestation over this nine-year period would be $8901 \mathrm{~km}^{2} \mathrm{yr}^{-1}$, a reduction of $25.6 \%$ below the current rate; also much less than the $40 \%$ people expect as a minimum reduction.

After 2017, the plan calls for 'zero illegal deforestation'. The key word is 'illegal,' which opens the door to any amount of deforestation so long as it is classified as 'legal.' The PNMC report's graph of projected deforestation (Brazil, Comitê Interministerial sobre Mudança do Clima 2008, p. 12) implies that $5000 \mathrm{~km}^{2} \mathrm{yr}^{-1}$ would be being deforested, presumably 'legally', from 2017 onwards. It should be noted that several proposals are currently under discussion in Brazil that call for allowing significantly more 'legal' deforestation, including a proposal by the Minister of Agriculture to forgive essentially all past illegalities and more than double the percentage of each property that can be cleared legally. The force of the 'ruralist block,' which represents large landholders in Brazil's National Congress, was demonstrated by their recently obtaining a oneyear postponement of all environmental fines. In addition, the current legislation can be manipulated to legalize deforestation of up to $80 \%$ of the areas in Amazonian properties (see Lima \& Capobianco 2009).

The PNMC claims that 4.8 billion tonnes of $\mathrm{CO}_{2}$ emission would be avoided over the 2009-2017 period. This is equivalent to 1.31 billion tonnes of carbon, obtained by multiplying by 12 (the atomic weight of carbon) and dividing by 44 (the molecular weight if $\mathrm{CO}_{2}$ ). At the $100 \mathrm{t} \mathrm{C} \mathrm{ha}^{-1}$ carbon stock mentioned in the report, this amount of carbon is equivalent to 13.1 million hectares, or $130909 \mathrm{~km}^{2}$ of avoided deforestation over the period, an average of $14545 \mathrm{~km}^{2} \mathrm{yr}^{-1}$ (optimistically assuming, from the point of view of area implications, that the replacement for forest is a parking lot with no biomass). Adding the $8901 \mathrm{~km}^{2} \mathrm{yr}^{-1}$ average that the plan would allow to be deforested, the baseline deforestation rate implied is $23447 \mathrm{~km}^{2} \mathrm{yr}^{-1}$, or approximately double the 2008 rate of clearing. The 4.8 billion tons of $\mathrm{CO}_{2}$ claimed to be the benefit of the plan would therefore be mainly 'hot air', or claimed emissions reductions with no real benefit for climate because they represent business as usual.

How would deforestation be reduced? This is the crucial question in terms of the plan achieving the results it proposes. The PNMC's section on 'studies in the area of mitigation' (Brazil, Comitê Interministerial sobre Mudança do Clima 2008, pp. 97-101) gives a long list of measures that range from land-fill methane capture to biofuels. These actions have been much criticized as being only a laundry list of already-existing programmes. Most important, however, is that the 'studies in the area of mitigation' contain no mention of Brazil's largest opportunity in this area, namely avoiding emissions from deforestation.

On the subject of reducing deforestation, the section on 'Measures to reduce deforestation' (Brazil, Comitê Interministerial sobre Mudança do Clima 2008, pp. 6163) contains a list of government actions in this area, all of which are good things to be doing. However, the most obvious measure is conspicuously missing: suspension of any of the planned infrastructure that would open up vast areas of currently inaccessible rainforest to entry of the actors and processes of deforestation. The PNMC calls for more inspectors, but containing deforestation would also require restraining highway construction, for example the BR319 (Manaus-Porto Velho) Highway that would open central and northern Amazonia to migration from the notorious 'arc of deforestation' in the southern part of the region (see Fearnside \& Graça 2006).

In summary, Brazil's National Plan for Climate Change is a positive change from the past, when quantitative discussion about reducing deforestation and emissions was virtually taboo. However, the PNMC is significantly less than is needed to control deforestation, much less leverage the international commitment needed to contain global warming within a reasonable limit, such as $2^{\circ} \mathrm{C}$. Brazil needs to move quickly to take the lead in the effort to halt global warming, because it is one of the countries with the most to lose from global warming, it is one of the countries with the least painful option for greatly reducing its emissions (i.e. by reducing deforestation) and because its deforestation continues to make a significant contribution to the global total greenhouse gas emissions.

\section{Acknowledgements}

I thank Conselho Nacional do Desenvolvimento Científico e Tecnológico (CNPq: Proc. 305880/2007-1), Rede GEOMA and Instituto Nacional de Pesquisas da Amazônia (INPA: PRJ13.03) for financial support. Two anonymous referees made helpful comments. 


\section{References}

Brazil, Comitê Interministerial sobre Mudança do Clima (2008) Plano Nacional sobre Mudança do Clima - PNMC - Brasil. Ministério do Meio Ambiente, Brasília, DF, Brazil: 129 pp. (www document). URL http://www.mma.gov.br/estruturas/ imprensa/_arquivos/96_01122008060233.pdf

Brito, B. (2009) Multas Pós-Operação Curupira no Mato Grosso. IMAZON: O Estado da Amazônia, No. 12. Instituto do Homem e Meio Ambiente na Amazônia (IMAZON), Belém, Pará, Brazil: 4 pp. (www document). URL http://www.imazon.org.br

Cox, P.M., Harris, P.P., Huntingford, C., Betts, R.A., Collins, M., Jones, C.D., Jupp, T.E., Marengo, J.A. \& Nobre, C.A. (2008) Increasing risk of Amazonian drought due to decreasing aerosol pollution. Nature 453: 212-215.

Fearnside, P.M. \& Graça, P.M.L.A. (2006) BR-319: Brazil's Manaus-Porto Velho Highway and the potential impact of linking the arc of deforestation to central Amazonia. Environmental Management 38(5): 705-716.

Hare, B. \& Meinshausen, M. (2006) How much warming are we committed to and how much can be avoided? Climatic Change 75: 111-149.

Lima, A. \& Capobianco, J.P.R. (2009) Alcance territorial da legislação ambiental e a consolidação do uso agropecuário de terras no Brasil. Instituto de Pesquisas Ambientais da
Amazônia (IPAM), Belém, Pará, Brazil: 5 pp. (www document). URL http://www.climaedesmatamento.org.br/uploads/livros/ 18135df03aa6143c3b22eeeb101a42fa2678374e.pdf

Lima, A. \& Capobianco, J.P.R. \& Moutinho, P. (2009) Desmatamento na Amazônia: Medidas e efeitos do Decreto Federal 6.321/07. Instituto de Pesquisas Ambientais da Amazônia (IPAM), Belém, Pará, Brazil: 14 pp. (www document). URL http://www.climaedesmatamento.org.br/uploads/ livros/f2c4f9fb5f6c9c7c2bb04e04ffad6207eb379378.pdf

Meinshausen, M., Meinshausen, N, Hare, W., Raper, S.C.B., Frieler, K., Knutti, R., Frame, D.J. \& Allen, M.R. (2009) Greenhouse-gas emission targets for limiting global warming to $2^{\circ}$ C. Nature 458: 1158-1162.

Nepstad, D., Stickler, C.M. \& Almeida, O.T. (2006) Globalization of the Amazon soy and beef industries: Opportunities for conservation. Conservation Biology 20: 1595-1603.

UN-FCCC (1992) United Nations Framework Convention on Climate Change, Bonn, Germany. (www document). URL http://www.unfccc.de

\section{PHILIP M. FEARNSIDE}

National Institute for Research in the Amazon (INPA), CP 478, Manaus-Amazonas, 69011-970, Brazil

e-mail:pmfearn@inpa.gov.br 